\title{
The Axes of Resilience: The Case of the Earthquakes of September 7 and 19, 2017 in Mexico
}

\author{
Joel F Audefroy* \\ Escuela Superior de Ingenieria y Arquitectura,Unidad Tecamachalco, Instituto Politecnico Nacional, Mexico
}

*Corresponding author: Joel F Audefroy, Higher School of Engineering and Architecture, Tecamachalco Unit, National Polytechnic Institute, Mexico

Submission: 毕June 20, 2018; Published: 眥July 10, 2018

\section{Introduction}

The year 2017 was marked by a series of hydrometeorological and geological events of different sizes that hit Mexico in different parts. The first event was the storm Lydia, on September 1, which left seven deaths, damage to communication routes, urban infrastructure, hospital, housing, drinking water, drainage, electricity, cell phone and more than 6,000 evacuated to temporary shelters. The second event was Hurricane Katia, on September 8 that entered 20 kilometres from Tecolutla, Veracruz. It reached category $2(195 \mathrm{~km} / \mathrm{h})$ and when it touched the ground it weakened to category 1 . It caused intense rains in 11 entities with more than $250 \mathrm{~mm}$. More than 4000 people were evacuated from the States of Veracruz and Puebla. Around 77,000 people were without electrical power during the storm. Affectations were reported in 256 homes, 36 landslides, 2 subsidence and 10 rivers exceeded their maximum levels, and a river overflowed in Oaxaca. The third event was Hurricane Max, on September 14 that touched down in Pico del Monte, Guerrero. Then it was degraded to a category 1 tropical storm. In the State of Guerrero, it caused the flooding of 1,513 homes and at least 800 people evacuated. Five localities were isolated, 2 temporary road sections closed and 17 rivers overflowed by heavy rains.

The earthquakes of September 7 and 19 increased the destruction and left hundreds of families affected. On September 7, an 8.2 category earthquake with epicenter in the Gulf of Tehuantepec affected mainly the states of Chiapas and Oaxaca. The affected dwellings were 63,335 in Oaxaca, 58,366 in Chiapas, and 712 in Tabasco. 1,075 schools were affected in Oaxaca and 1,571 in Chiapas. 462 heritage buildings, 90 health units, and 194 public buildings were affected with partial or total destructions. On September 19 another 7.1 magnitude earthquake with epicenter in Axochiapa, Morelos affected 8 states including Mexico City. A total of 50,610 homes were affected, 83 health units, 133 temples and 16,136 schools were affected and there was a total of 369 deaths.

In 1985, the September 19 earthquake that affected Mexico City had a balance of 100,000 damaged homes and an undetermined number of deaths $(12,000$ or more $)$. In economic terms, the earthquake of 1985 had an economic impact of 170,000 million pesos (mdp), equivalent to $2.4 \%$ of GDP in 1985 . In exchange for 2017, the preliminary cost of reconstruction for the September earthquakes amounts to $48,000 \mathrm{mp}$. These data tend to confirm the importance of disaster prevention and integrated risk management (IRM).

The Different Resiliences: Technical, Institutional, Social and Cultural, and Financial

The United Nations Program for Human Settlements (UNHABITAT) established the Urban Resilience Profile Program (URPP) to define areas of opportunity in the wake of disasters. The program defines four technical sectors of resilience: water supply, electricity, housing and telecommunications.

\section{Technical (water, energy, housing and telecom)}

One of the first consequences of an earthquake, flood or a hurricane is the rupture of pipes and aqueducts, which leads to the suspension of drinking water services. The impact on health and survival can be dramatic. In the wake of the earthquake of September 19, 2017 in Mexico, 6 million people were left without water. In the Valley of Mexico, 15 days later, the operation of the hydraulic network had recovered $94 \%$. That is to say that the resilience worked, but after 15 days. The supply of drinking water should be able to respond quickly to a destructive natural phenomenon. In the Valley of Mexico this recovery involved the collaboration and coordination of various agencies: The National Water Commission (CONAGUA), the Water System of Mexico City (SACM), the Valley of Mexico Water Basins Organization (OCAVM) and the Water Commission of the State of Mexico (CAEM).Energy is another basic infrastructure whose supply is vital for the recovery of cities. In the earthquake of September 19, 2018, 1,972 light posts were affected, 19 damaged high voltage lines, 754 damaged transformers and 4.8 million homes and businesses were affected. A day later the electric power service had been restored by $95 \%$. 
The balance of the earthquakes of September 7 and 19, 2017, was 184,000 damaged homes. This number exceeds the 150,000 homes that were built nationwide during 2016. To address this situation, the SEDATU (Secretariat of Agrarian, Territorial and Urban Development) delivered bank cards with balances of 120.00 pesos for reconstruction of destroyed houses and 15,000 pesos for the repair of houses with partial damages. INFONAVIT, meanwhile, launched ten measures to meet the demand for housing. The agency identified that its borrowers would correspond 980 homes with total loss and 7,500 homes with some affectation. In the case of Oaxaca, there are 26,949 homes with total damage to be rebuilt; in Chiapas 14 thousand 73; in Morelos six thousand 104; in Guerrero two thousand 485; in Puebla five thousand 638; in the State of Mexico two thousand 701 and in Mexico City two thousand 351 that add 60 thousand 302 homes.

In the telecommunications sector, as a result of the earthquakes there were intermittencies and falls in the service, but it recovered over the following hours. There were 75,000 failures in voice service and 104,000 in data services. 144 telecommunications infrastructure sites were affected in Mexico City, State of Mexico and Morelos.

\section{Institutional (plans and programs for Integrated risk management)}

In general, the institutional plans and programs have not been designed for post-disaster resilience. However, some instruments, such as risk maps, can play a key role in resilience. The risk maps reveal the areas of the territory where the greatest risks and threats are located and, consequently, indicate where there is no need to proceed with a reconstruction program. Housing programs are designed outside of risk considerations, and therefore do not have a relevant role in resilience. With the exception of some financial institutions such as INFONAVIT that offers loans with preferential rates for victims.

\section{Social (social organization, participation, social networks) and Cultural (local knowledge, collective memory]}

As a result of the earthquakes of 2017 there was considerable social mobilization at different levels: rescuers, social networks, to provide support of all kinds. Technical assistance by professionals for the reconstruction, such as the Morelos Bioreconstruye network, donors of materials and equipment, courses to rebuild with land in Oaxaca and Morelos, neighbourhood associations that mobilized to give support to the affected neighbours. Both Twitter and Facebook and Flickr are tools usually consulted by users in the event of a disaster, but they are instruments of communication rather than tools of resilience. What makes a resilient society is its ability to organize itself immediately following a disaster. Also, their ability to participate is part of resilience and a little participatory society (which leaves everything in the hands of the state) will have little capacity for resilience.

\section{Financial (aid funds, insurance and private and public resources)}

The resilience capacity is also measured by the financial capacity of different sectors to contribute in the wake of a disaster. In Mexico there are different financial sectors that have contributed, without counting international aid:

1) The NGO sector (Mexican Red Cross, Apostolic Nuncia in Mexico, World Vision)

2) The insurance sectors

3) The federal government (Banobras, FONDEN)

4) International organizations (World Bank, UNICEF)

5) The private sector.

We must distinguish between who contributes the resource and who administers it. For example, the Mexican Red Cross manages resources from different sectors: private, deputies, senators, external donations. UNICEF also manages resources from the private sector and FONDEN manages resources from the World Bank.

Likewise, it is necessary to distinguish between who provides financing and who uses and organizes them. For example, the Mexican Red Cross receives donations, manages them but also carries out multiple emergency actions: organization of volunteers in affected areas, rescue work, delivery of tons of aid (bed camps, tents and kitchen kits), ambulance and medical attention.

The State, through the DN3 program, sends elements of the Navy to supervise and help rescues, but has no role in reconstruction and resilience. Likewise, the State through the municipalities organizes emergency shelters (46 in the CDMX, 15 in the State of Mexico, 2 in Puebla, 21 in Oaxaca, 34 in Chiapas, 72 in Morelos and 6 in Guerrero) in the emergency stage and organizes FONDEN resources for reconstruction.

The insurance sector has mainly supported the private and public sector with the insurance contracted for the Historical Monuments of INAH. According to the Mexican Association of Insurance Institutions (AMIS), the cost of the earthquakes of 2017 rises to the amount of 16,449 million pesos, mainly for damage to buildings $(13,491$ million pesos) and catastrophic bonds of the Government of Mexico (2,861 million pesos).

The private sector was organized in the face of the disaster of 2017 with the creation of the Fuerza México private trust and a contract with Nacional Financiera was signed a day after the earthquake on September 20. The Trust does not receive or exercise public resources and is oriented to administer and operate the resources and donations made by business organizations and individuals. This trust supports the reconstruction (housing, schools, markets and temples) with $249 \mathrm{mp}$ in 6 municipalities of Oaxaca and 2 in Chiapas(Figure 1). 


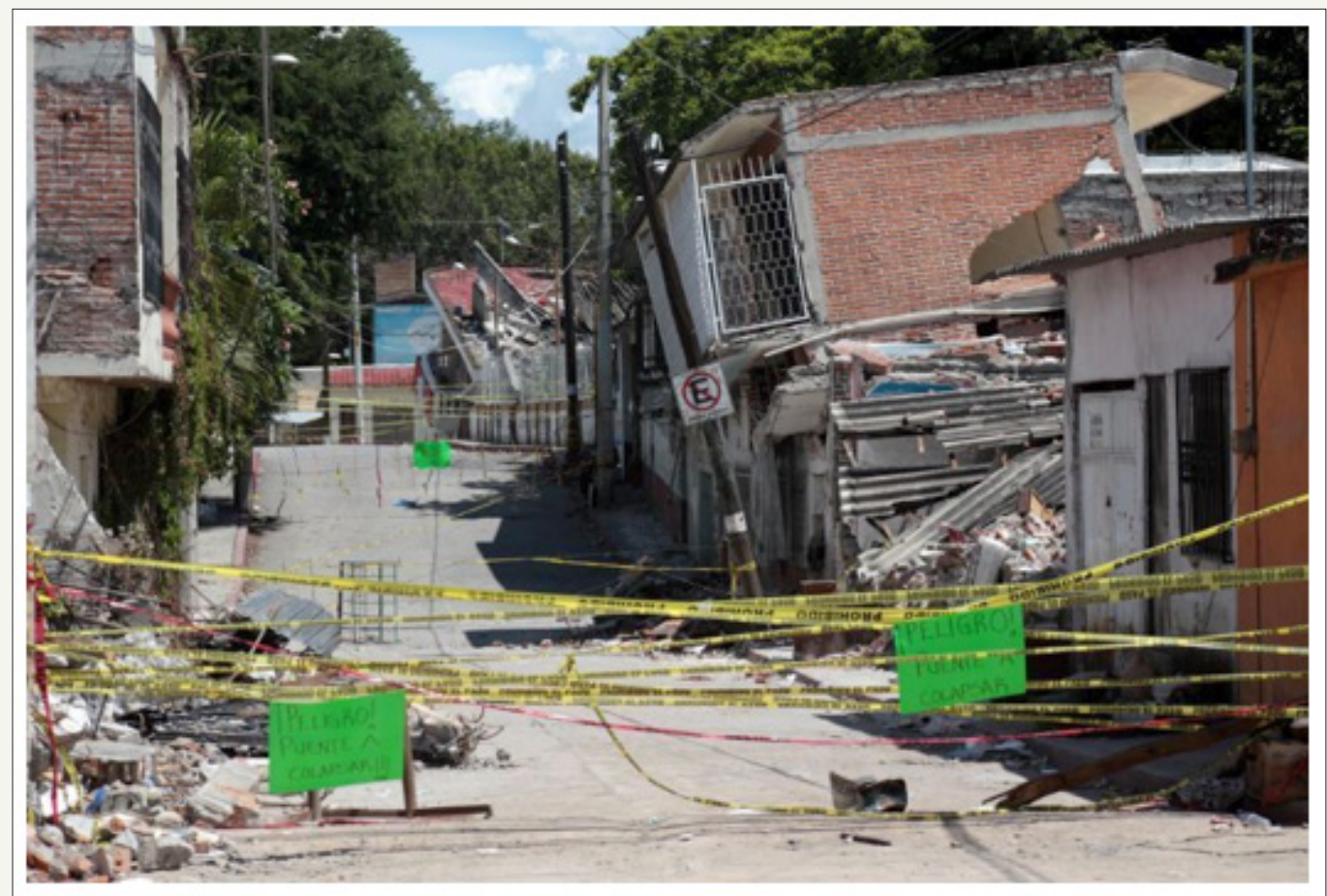

Figure 1: Earthquake in Jojutla, Morelos (source: Cuarto Oscuro2017).

\section{Conclusion}

To a certain extent we can affirm that there was a certain resilience in the cases of the earthquakes of September 7 and 19, 2017 in Mexico. However, in the housing sector, still, in June 2018, there are families left homeless who have not recovered from the disaster. They have not yet recovered a home, especially in cases where there was total loss. The Secretariat of Agrarian, Territorial and Urban Development (Sedatu) reported on June 2018 that there is a 75 percent lack in the reconstruction of buildings in the seven states affected by the September earthquakes. The process of reconstruction of the 60 thousand houses that resulted with total damage by earthquakes recorded an advance of more than 25 percent, which is equivalent to 17 thousand 317 properties. That is to say, almost 10 months after the earthquake, recovery is very slow.It is worth mentioning that financial resilience (insurance) also worked very slowly, since the insurance for damaged heritage buildings has been handed over to INAH very slowly.The sectors that have responded with much more efficiency are the water, electricity and telecommunications sectors. Nearly 10 months after the earthquake, these sectors have recovered to $100 \%$. (c) (i) Creative Commons Attribution 4.0

For possible submissions Click Here
Submit Article

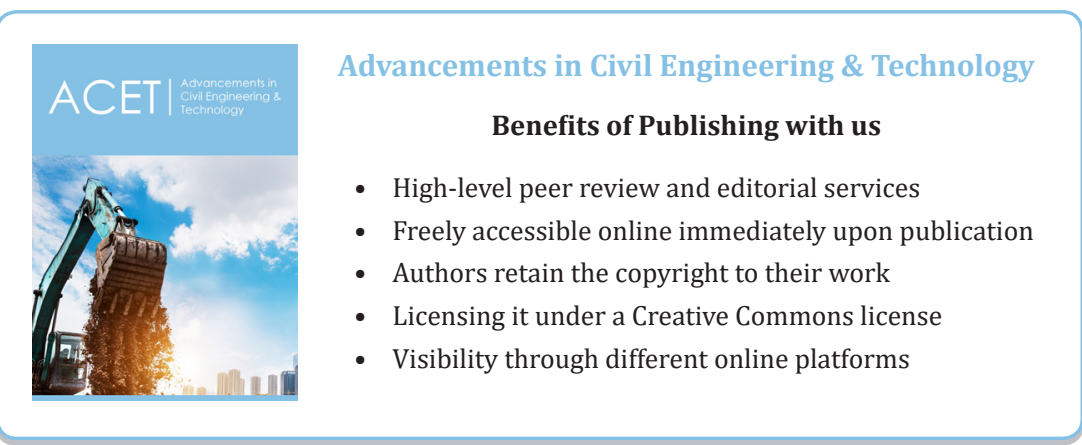

